\title{
A Note On The Determinants Of Geographic Cost-Of-Living Differentials: The Case Of Canada
}

\author{
Anthony Ostrosky*
}

I.

In a recent issue of Land Economics, Cebula (1980) investigates empirically the determinants of geographic living-cost differentials among SMSA's in the United States. For the year 1975, Cebula finds that greater population density, higher per capita incomes, and higher property tax levels all act to raise the cost of living whereas, greater population size and the existence of right-to-work laws both act to lower the cost of living.

The purpose of this brief note is to ascertain the determinants of geographic living-cost differentials in Canada. The analysis focuses upon living-cost differentials among Census Metropolitan Areas (CMA's) in Canada in the year 1976. The model estimated is an adaptation of Cebula's model (1980).

II.

The model to be estimated is given by:

$$
\mathrm{C}_{\mathrm{i}}=\mathrm{a}_{0}+\mathrm{a}_{1} \mathrm{D}_{\mathrm{i}}+\mathrm{a}_{2} \mathrm{P}_{\mathrm{i}}+\mathrm{a}_{3} \mathrm{Y}_{\mathrm{i}}+\mathrm{a}_{4} \mathrm{~T}_{\mathrm{i}}+\mathrm{a}_{5} \mathrm{U}_{\mathrm{i}}+\mathrm{a}_{6}
$$

where $C_{i}=$ the average cost of living for a four-person family living on an intermediate budget, in $\mathrm{CMA}_{\mathrm{i}}$, 1976, expressed in current dollars (Canadian),

$\mathrm{D}_{\mathrm{i}}=$ the population density in $\mathrm{CMA}_{\mathrm{i}}, 1976$, in terms of thousands of persons per square mile,

$\mathrm{P}_{\mathrm{i}}=1976$ total population in $\mathrm{CMA}_{\mathrm{i}}$,

$\mathrm{Y}_{\mathrm{i}}=1975$ per capita income in $\mathrm{CMA}_{\mathrm{i}}$,

$\mathrm{T}_{\mathrm{i}}=1974$ per capita property tax level in $\mathrm{CMA}_{\mathrm{i}}$, 


$$
\begin{aligned}
& \mathrm{U}_{\mathrm{i}}=\begin{array}{l}
\text { percentage of CMA } \\
\text { that was formally unionized, } 1976,
\end{array} \\
& \mathrm{a}_{0}=\text { constant, and } \\
& \mathrm{a}_{6}=\text { stochastic error term. }
\end{aligned}
$$

The data pertain to some 21 CMA's $^{1}$ in Canada and were obtained from the Canada Year Book, 1978-79 and Statistics Canada. The model is structurally identical to Cebula's except that $U_{i}$ replaces Cebula's right-to-work dummy variable.

The OLS estimate of (1) is given by:

$$
\begin{aligned}
& \mathrm{C}_{\mathrm{i}}=10,104.16+0.4021 \mathrm{D}_{\mathrm{i}}-0.0002 \mathrm{P}_{\mathrm{i}}+0.8072 \mathrm{Y}_{\mathrm{i}}+ \\
& (+2.71) \quad(-1.98) \quad(+3.61) \\
& 2.9681 \mathrm{~T}_{\mathrm{i}}+0.6048 \mathrm{U}_{\mathrm{i}}, \mathrm{DF}=15, \mathrm{R}^{2}=.59, \mathrm{~F}=11.98 \\
& (+1.79) \quad(+3.98)
\end{aligned}
$$

with terms in parentheses being t-values.

III.

The results in (2) are qualitatively compatible with those obtained by Cebula (1980). In particular, it appears that greater population density, higher per capita income, higher property tax levels, and a greater degree of unionization all act to raise the cost of living in Canadian CMA's. On the other hand, greater population size tends to act to lower the cost of living in CMA's.

\section{FOOTNOTES}

'The 21 CMA's for which geographically comparable living-cost data were available were Calgary, Edmonton, Halifax, Hamilton, Kitchener, London, Montreal, Ottawa-Hull, Quebec, Regina, St. Catharines-Niagara,

St. John's (Nfld.), Saint John (N.B.), Saskatoon, Sudbury, Thunder Bay, Toronto, Vancover, Victoria, Windsor, and Winnipeg. 


\section{Volume 10}

\section{AUTHOR INDEX}

Benson, Bruce L., "The Impact of Entry at a Distance on Market Demand," No. 2, p. 62.

Christensen, Paul P., "A Reconsideration of the Physical Laws for Transforming Environmental Resources in Post-Keynesian Production Theory," No. 1, p. 1.

Colwell, Peter F., "Value Of Multi-Family Housing," No. 3 p. 60.

Cumberland, John H., "Efficiency and Equity in Interregional Environmental Management," No. 2, p. 1.

Dunn, Edgar S., Jr., "The Future Isn't What It Used To Be," No. 3, p. 1.

Evans, Richard D., "Probablistic Income-Maximizing Behavior in Regional Migration: An Empirical Test," No. 1, p. 48.

Fritz, Richard G., "A Reconsideration of the Physical Laws for Transforming Environmental Resources in Post-Keynesian Production Theory," No. 1, p. 1.

Gordon, John R., "Using the Shift-Share Technique in Economies with Widely Varying Sectoral Growth Rates: Observations and a Suggested Model Modification," No. 1, p. 57.

Hackett, William B., "Using the Shift-Share Technique in Economies with Widely Varying Sectoral Growth Rates: Observations and a Suggested Model Modification," No. 1, p. 57.

Haynes, Kingsley E., "A Multiobjective Power Plant Location Model With Hierarchical Screening: Nuclear Power in Northern Indiana," No. 3, p. 9.

Henry, Mark, "A Note on Nonsurvey Input-Output Models for Multicounty Regions," No. 1, p. 68.

Houston, David, "A History of the Process of Capital Accumulation in Pittsburgh: A Marxist Interpretation-Part III," No. 2, p. 20.

Khalili, Amir, "Optimum Location and the Theory of Production: A Comparative Static Analysis," No. 2, p. 10.

Krmenec, Andrew J., "A Multiobjective Power Plant Location Model With Hierarchical Screening: Nuclear Power in Northern Indiana," No. 3, p. 9.

Lee, Feng-Yao, "Estimation of a System Model of Regional Income Differentials," No. 3 , p. 48 .

Loviscek, Anthony L., "Changing Input-Output Coefficients: The Case of West Virginia," No. 1, p. 14.

Mak, James, "The Choice of Journey Destinations and Lengths of Stay: A Micro Analysis," No. 2, p. 38.

Martin, Julia H., "An Analysis of Population Growth Rates Within Typological Categories of Small Southern Cities," No. 1, p. 29.

Mirakhor, Abbas, "Optimum Location and the Theory of Production: A Comparative Static Analysis," No. 2, p. 10.

Moncur, James E. T., "The Choice of Journey Destinations and Lengths of Stay: A Micro Analysis," No. 2, p. 38.

Moses, Ronald, "Company Size and the Decentralization of Manufacturing," No. 2, p. 49.

Mulkey, David, "Using the Shift-Share Technique in Economies with Widely Varying Sectorial Growth Rates: Observations and a Suggested Model Modification," No. 1, p. 57.

Ostrosky, Anthony, "A Note on the Determinants of Geographic Cost-of-Living Differentials: The Case of Canada," No. 3, p. 68. 
Persky, Joseph, "Company Size and the Decentralization of Manufacturing," No. 2, p. 49.

Richetto, Jeffrey P., "Small Town Central City Revitalization: An Assessment of Need and Criteria," No. 3, p. 32.

Serow, William J., "An Analysis of Population Growth Rates Within Typological Categories of Small Southern Cities," No. 1, p. 29.

Serow, William J., "The Role of Long Distance Migration in the Rural Renaissance, In Gentrification, and in Growth of the Sunbelt," No. 3, p. 23.

Sirmans, C. F., "Value of Multi-Family Housing," No. 3, p. 60.

Solomon, Barry D., "A Multiobjective Power Plant Location Model With Hierarchical Screening: Nuclear Power In Northern Indiana," No. 3, p. 9.

Spar, Michael A., "An Analysis of Population Growth Rates Within Typological Categories of Small Southern Cities," No. 1, p. 29.

Weinstein, Robert I., "Probablistic Income-Maximizing Behavior in Regional Migration: An Empirical Test," No. 1, p. 48. 